\title{
Microbialitic structures in the Sarmatian carbonate deposits from Şimleu Basin, Romania
}

\author{
Hyam DAOUD, Ioan I. BUCUR* \& Călin BRUCHENTAL \\ “Babeş-Bolyai” University, Department of Geology, Kogălniceanu 1, 400084 Cluj Napoca, Romania
}

Received December 2005; accepted July 2006

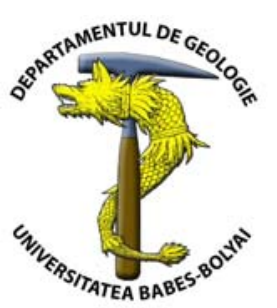

\begin{abstract}
The Sarmatian deposits from the Şimleu basin are developed in two facies: terrigenous and calcareous. An attempt to distinguish the main types of Sarmatian limestone microfacies was made by Bucur et al. (1992). The present study provides more detail of the sedimentary facies and fabrics of these limestones, emphasizing the essential contribution of microbialites to their formation. The following types of microbialite and microbial structure were found: (1) thrombolites with clotted fabric and fenestral structures; (2) microbial crusts on bioclasts; (3) peloidal microbialites (4) agglutinated microbialites; (5) stromatolites and laminoid-fenestral structures. All these structures played an important role in the accretion of the Sarmatian carbonate deposits in the area studied.
\end{abstract}

Key words: Microbialites, mounds, limestone, Sarmatian, Şimleu Basin, Romania.

\section{INTRODUCTION AND BRIEF HISTORICAL OVERVIEW}

The Şimleu Basin is one of five Neogene basins that formed due to the collapse of crystalline basement between Plopiş and Meseş Mountains. The basement of the Şimleu Basin consists of crystalline rocks overlain by PermianTriassic, Upper Cretaceous and Paleogene deposits. The basin fill comprises Neogene and Quaternary formations.

Sarmatian carbonates of the Şimleu Basin were first studied in the second half of the XVIIIth century, when Matyasovzky (1881) mentioned Sarmatian limestones from the Tusa area. Subsequently, Kräutner (1938), Paucă (1954, 1964), Givulescu (1957), Nicorici (1958, 1962, 1963) and Chivu et al. (1964) also referred to these deposits. More recently, Nicorici (1972), Clichici (1971, 1973), Nicorici and Neagă (1976), Berekméri (1980-1981), Bucur and Nicorici (1992) and Bucur et al. (1992) published new data on the Sarmatian carbonate deposits in the area.

\section{DESCRIPTION OF THE STUDIED SECTIONS}

Sarmatian reef limestones crop out on the margin of the Plopiş Mountains between Tusa and Halmăşd, in general as small patches with areas from tens of $\mathrm{m}^{2}$ up to $1000 \mathrm{~m}^{2}$.

Six lithological columns have been studied within these outcrop areas (Fig. 1).

\section{Tusa}

Sarmatian limestones crop out in Dobrei Hill as isolated rock bodies on the slope towards the Baciului Valley. They show conglomeratic features and surficial alteration. On weathering surfaces, laminated structures with annelid tubes and large numbers of gastropods can be noticed. Locally, the deposits are coquinas, often with crusts surrounding the bioclasts (Fig. 2A).

\section{Fizeș}

Sarmatian limestones with dome structures (thrombolitic granular mounds) crop out at the periphery of the Fizes valley, along the road to Dumbrava Hill. Some of these are laminated and are rich in bryozoans, annelids and successive thrombolite crusts. Towards the top of the outcrop, miliolids, annelid tubes and microbialites are present in abundance. On the western slope of the Dumbrava Hill, three other smaller outcrops of Sarmatian limestones occur, consisting of domes with bryozoans, annelid tubes and microbialite crusts (Fig. 2B)

\section{Plopiş \\ a. Varului Hill}

Sarmatian limestones crop out southwest of Plopiş, between the Racovița and Ghiurchii streams. Here they directly overlie the crystalline rocks and contain mollusc shells, numerous serpulid tubes, bryozoans, microbial crusts, calcareous algae, and rare foraminifers (Fig. 2C).

\section{b. The right slope of Ghiurchii Valley}

Very friable oolitic, granular bioclastic limestones occur in this area. The ooids formed around foraminifer tests, algal fragments or terrigenous particles.

\section{c. Lușoru Valley}

Stratified Sarmatian limestones in this area also directly overlie schists. The beds are centimeter-size in thickness and contain two clayey interlayers with limestone nodules. 
Carbonate nodules with worm tubes are characteristic of the upper part of the succession.

\section{Halmăşs}

The westernmost patches of Sarmatian limestones along the northeastern border of the Plopiş Mountains crop out in the neighborhoods of Halmăşd. In the abandoned quarry at Varului Hill, the Sarmatian limestones overlie crystalline rocks that form the hill between the Turei stream and its first left tributary. The Sarmatian limestones occur here as mounds with bryozoans, molluscs, foraminifers and worm tubes. Microbialite structures, often laminated, are also present.

Rhodophycean algae are common in the Tusa, Plopiş (Varului Hill) and Halmăşd, sections, being represented mainly by Titanoderma ucrainica and Mesophyllum sp. These forms indicate relatively shallow waters, around $5 \mathrm{~m}$ depth (Montaggioni and Camoin, 1993).

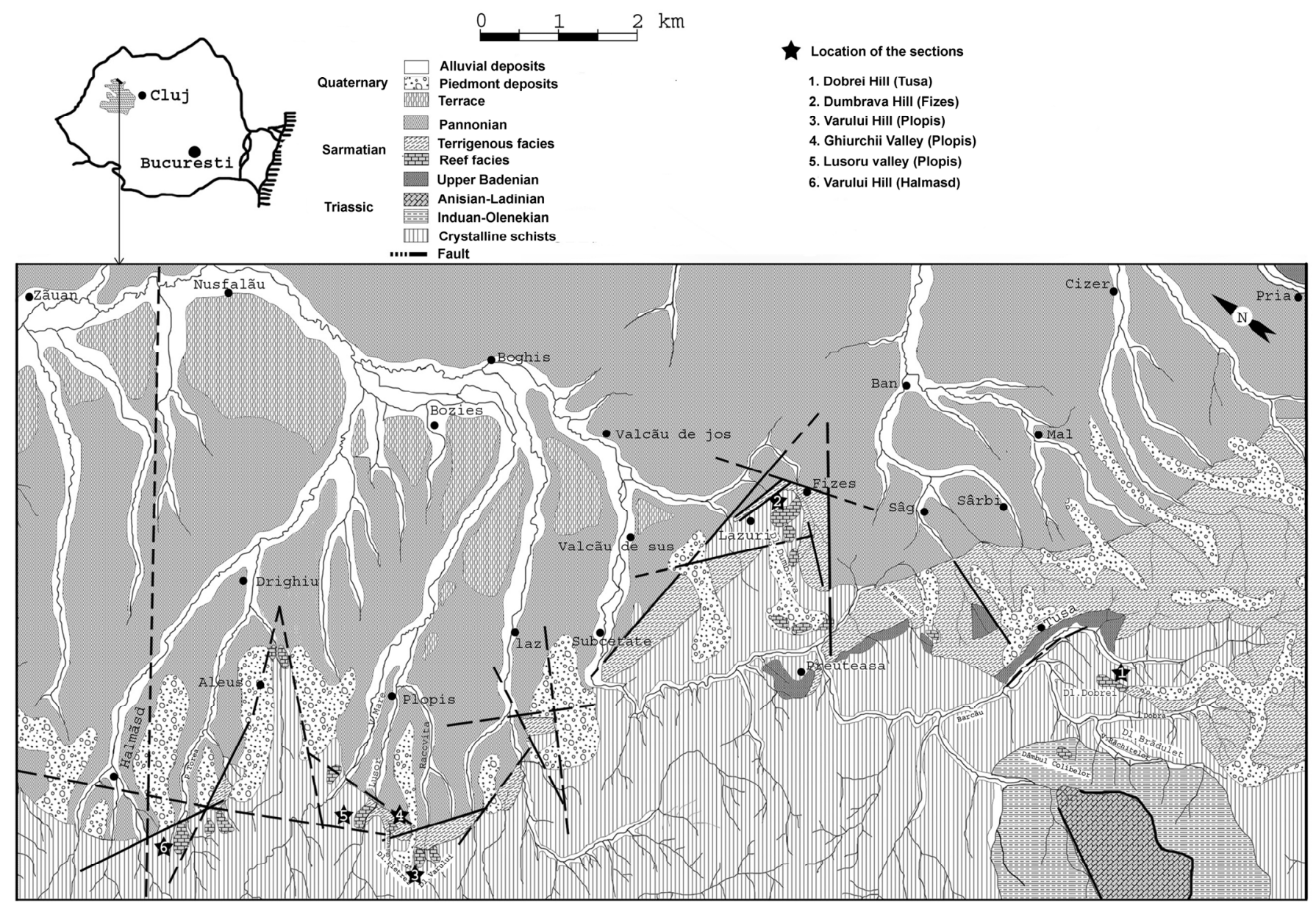

Fig. 1. Geological sketch-map of the studied region, with location of the limestone outcrops.

\section{MICROBIALITIC STRUCTURES}

Burne and Moore (1987) introduced the term "microbialite", which has since frequently been used. Microbialites represent the accretion and agglutination of fine sedimentary particles by microorganisms, especially by bacteria, cyanobacteria (Kennard and James, 1986), algae and encrusting organisms such as some small foraminifers and metazoans (Oliver et al., 2003). Microbialites are also the result of mineralization and biomineralization processes caused by some organisms during their lifetime, either at their surface, or inside the organic tissues (Riding, 1991; Flügel, 2004).

Microbialites have played an important role in the formation of carbonate deposits over geological time scales, during the Precambrian and the Phanerozoic, in marine, marginal-marine and non-marine environments. Some microbial structures have an age of 3.5 billion years (GarciaPichel et al., 2004). The most common microbialites during the Proterozoic were stromatolites, which were abundant between 2,800-1,000 Ma, while thrombolites and dendrolites become significant during the Paleozoic and Mesozoic (Riding, 2000).

The Cambrian-Ordovician, Carboniferous, and Late Permian-Middle Triassic were the intervals when microbialites flourished, especially in marine reef-related environments (Flügel, 2004). However, their development continued until the end of the Mesozoic, while during the Cenozoic the microbialites decreased in frequency in marine environments (Riding, 2000). Lately, knowledge on Cenozoic microbialites has significantly increased. For example, Saint-Martin et al. (2000) have described microbialites from coral reefs of Late Badenian age in the neighborhood of Budapest, where red algae, bryozoans and encrusting foraminifers played an important role. Also Saint-Martin et al. (1996, 1997) and Saint-Martin (2001) published data on Messinian microbialitic mounds (stromatolites and thrombolites) (Sicily, Italy) consisting of serpulids, bryozoans and nubeculariids, formed in a quiet shallow environment with rare storm episodes. The same authors have identified Messinian thrombolites and 
stromatolites rich in microbial peloids and fenestrate structures in the Mediterranean area (e. g., Morocco, Algeria, Spain).

Such thrombolitic mounds with bryozoans, red algae and encrusting foraminifers were also identified in Mississippian deposits from Arkansas (Webb, 1987) formed in quiet waters between 3-10 m depth. Shallow mounds consisting of corals and microbialites were common also during the Upper Jurassic along the northern Tethys border (Portugal and Spain) (Schmid et al., 2001).

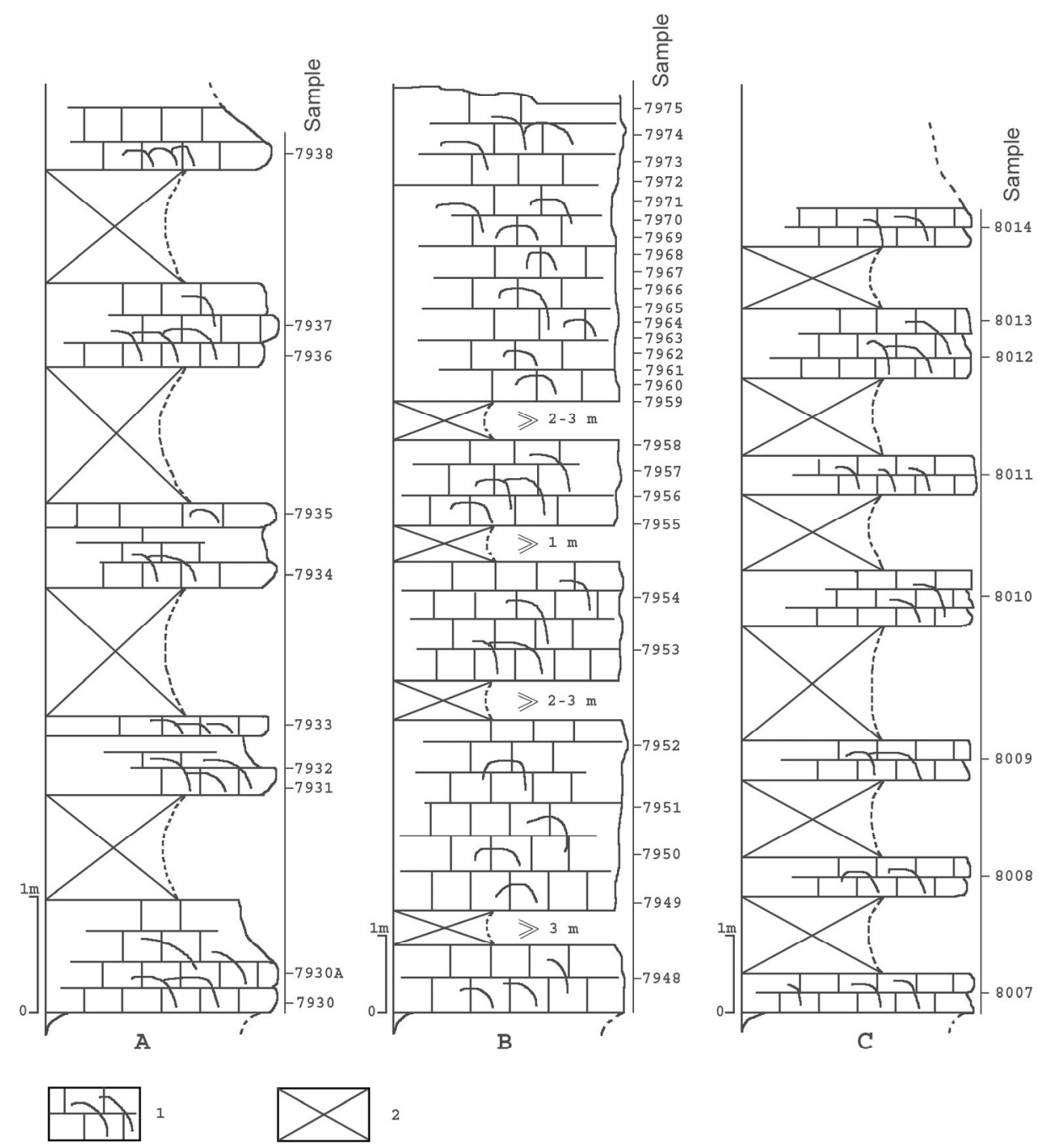

Fig. 2. Lithological succession of the Sarmatian limestones in the Tusa (A), Fizeş (B) and Plopiş (Varului Hill) (C) sections. 1-mound structures; 2-observational gap.

Moissette et al. (2002), Kershaw and Guo (2002), and Lucas and Montenat (1967) have provided additional data on microbial deposits. Jones and Hunter (1991) have identified Pleistocene microbialites on coral skeletons encrusted by red algae, foraminifers and worm tubes, in this case the microbialites being the main factors in the accretion of the fine sediment.

Shapiro (2000) has discriminated four structural scales in the study of microbialites: megastructure, macrostructure, mesostructure, and microstructure. In the profiles studied here within the Sarmatian limestones of the Şimleu Basin, we have identified microbial structures belonging to all the structural scales defined by Shapiro (2000):

- Megastructures are represented by mounds, consisting more or less of extended bioconstructions, in all the studied sections except for the one in Luşoru Valley (Fig. 4), where the limestones show a horizontal stratification. The mounds are 1-2 $\mathrm{m}$ high and 2-3 $\mathrm{m}$ width, and consist of bryozoans, serpulids, algae, and foraminifers. Sometimes they show significant terrigenous influx. SaintMartin et al. (1996) and Saint-Martin (2001) have identified similar mounds in Messinian formations (Sicily, Italy);
- Macrostructures consist of spherical forms with diameters between $30 \mathrm{~cm}$ and $1 \mathrm{~m}$ (Fig. 5).

- Mesostructures show horizontal, concentric and wavy laminations and obvious microbialite crusts (Fig. 6);

- Microstructures have been identified in thin sections.

More than 100 samples were studied in thin sections; the following microbialitic structures have been identified:

1. Thrombolites with clotted fabric, tubular fenestral structures, and irregular voids (Kennard and James, 1986; Burne, 1987), (Fig. 7A; Pl. III, Figs. 1, 3, 4). In general such structures represent $60-70 \%$ of the rock volume, being the dominant feature. They are associated with red algae crusts, encrusting foraminifers, serpulids, bryozoans and sometimes siliciclastic fragments consisting of quartz fragments.

2. Microbial crusts (Pl. I, Fig. 5; Pl. II, Fig. 6), consisting of microbial micrite besides small bioclasts and siliciclastic grains, or building-up micritic envelopes around some bioclasts, bryozoans and worm tubes.

3. Microbial peloids are widely represented in the rock. Many times such structures fill the intraskeletal space of the bryozoans (Pl. II, Figs. 1, 3) or of the worm tubes (Pl. III, Fig. 4). 
4. Agglutinated microbialites (Flügel, 2004) consisting of amalgamated peloids with cavities or fenestrae filled with sparitic cement giving birth to "stromatactis"-type structures. Due to the lack of distinctive lamination, such structures cannot be defined as stromatolites (Pl. II, Fig. 4)
5. Stratiform stromatolites (Figs. 7B, C; Pl. IV, Figs. 1, 6; Pl. V, Fig. 4) consisting of fine laminae and sometimes showing laminoid-fenestral structures (Kennard and James, 1986).

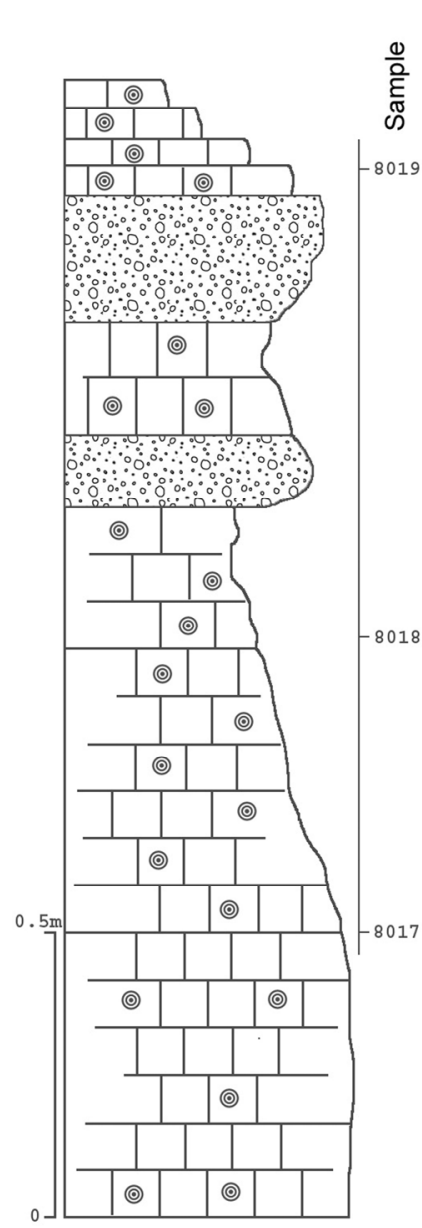

A

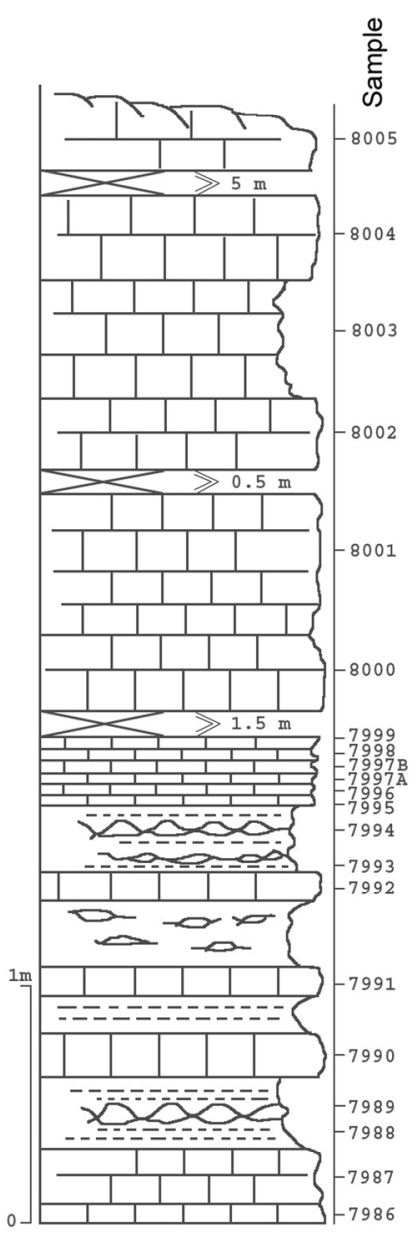

B

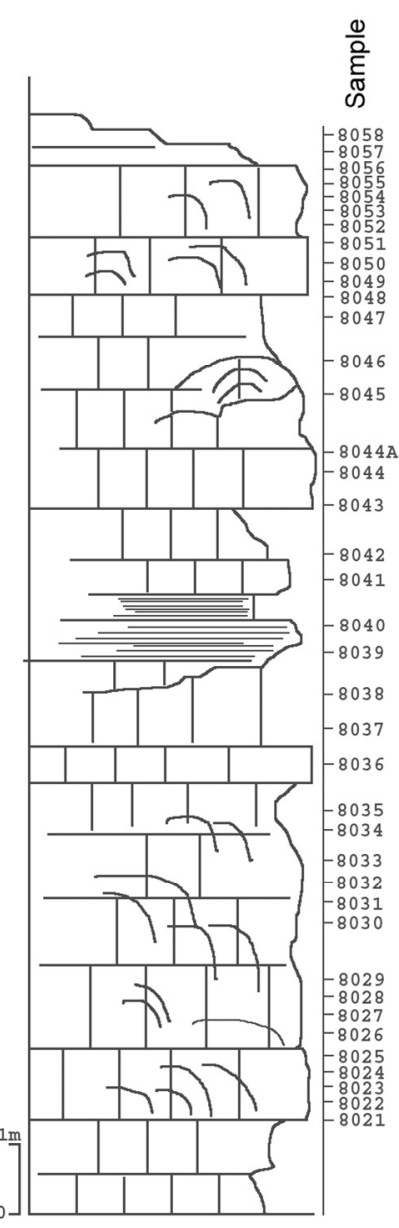

C

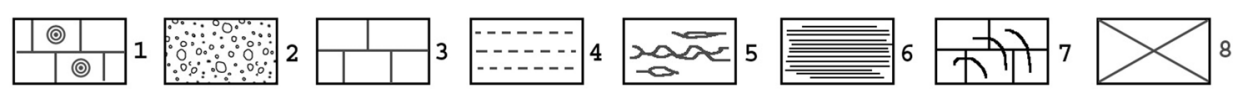

Fig. 3. Lithological succession of the Sarmatian limestones in the Plopiş (Ghiurchii Valley) (A), Plopiş (Luşoru Valley) (B) and Halmăşd (Varului Hill) (C) sections. 1-oolitic limestone; 2-conglomerates; 3-limestones; 4-shales; 5-limestone nodules; 6-laminated structures; 7-mound structures; 8-observational gap.

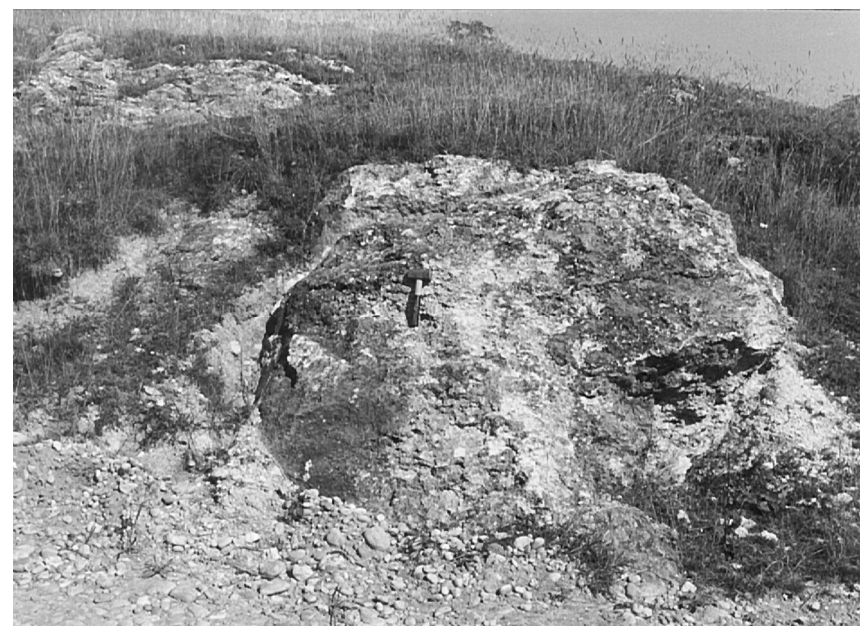

Fig. 4. Mound-structures at Dumbrava Hill (Fizeş).

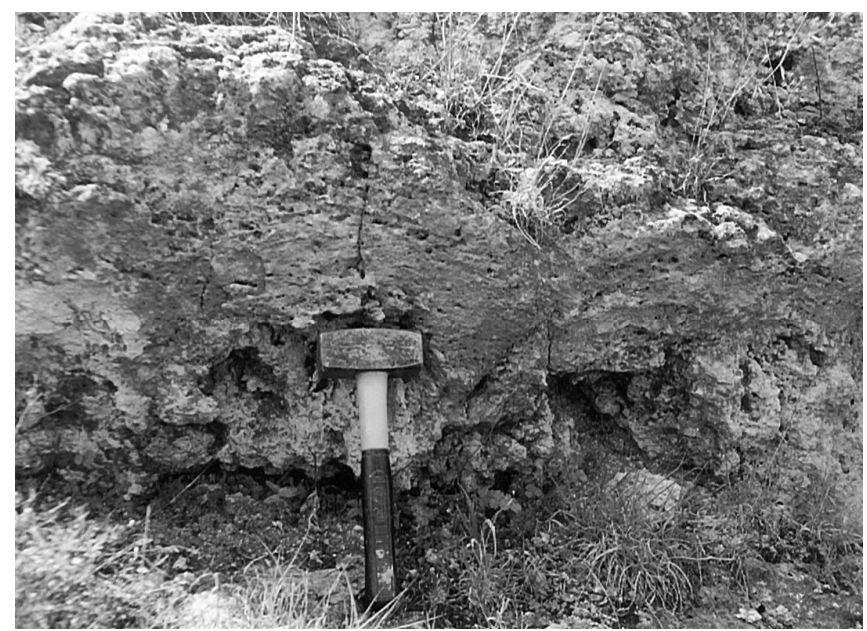

Fig. 5. Hemispherical bioconstructions inside a mound structure from Halmăşd (Varului Hill). 


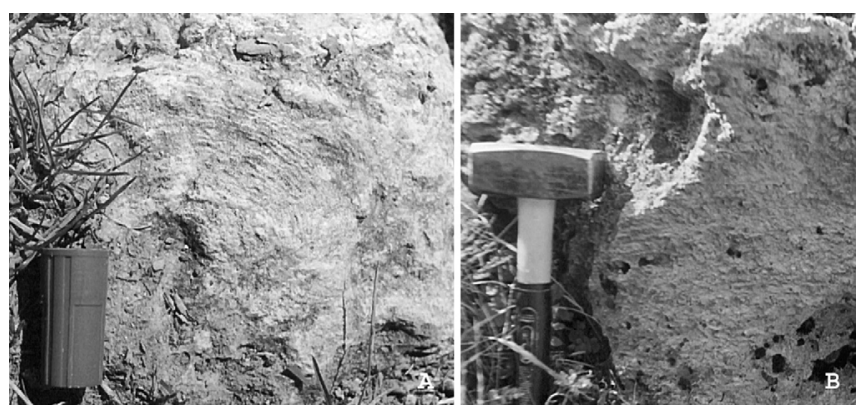

Fig. 6. Concentric mesostructures with bryozoans(A), and laminated mesostructures (B) (Halmăşd, Varului Hill).
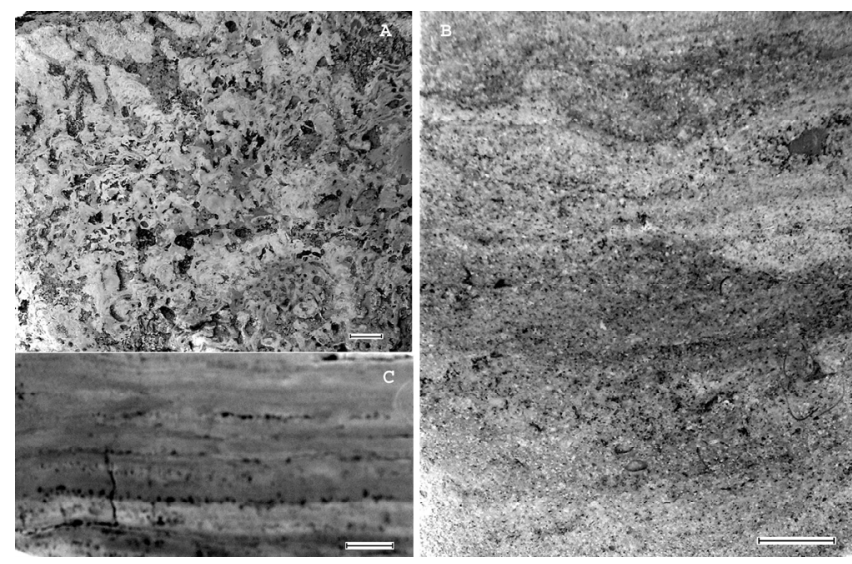

Fig. 7. Bioconstructions with red algae at Tusa (A); stratiform stromatolites from Halmăşd (Varului Hill) observed in polished surfaces $(B, C)$. Scale bar is $1 \mathrm{~cm}$.

\section{REMARKS AND CONCLUSION}

The microorganisms represented by microbes, algae, and encrusting foraminifers have played an important role in the accretion and agglutination of the fine sediments in these deposits, leading to the formation of microbialitic structures. The presence of a microbial film covering the substrate favored attachment of the bryozoan larvae. At the same time, the irregular bryozoan skeletons and their porous surfaces allowed the development of microbial communities, as a proof of the reciprocal interaction between the microbialites and the bryozoans.

Most commonly, the red algae Titanoderma ucrainica and Mesophyllum identified here live at about $5 \mathrm{~m}$ depth (Montaggioni and Camoin, 1993). On the other hand, the irregularly-shaped grains of terrigenous origin were transported short distances, indicating a shallow water depositional environment, close to the shoreline. According to Flügel (2004), the mixture of serpulids with siliciclastics, frequently identified in our samples, indicates a littoral sedimentary environment. The presence of vadose silt (Pl. II, Fig. 5), radiaxial fibrous cement (Pl. III, Fig. 6), and Microcodium (Pl. III, Fig. 5; Pl. IV, Fig. 4) indicates frequent subaerial exposure of these mounds.

To summarize, we infer formation of the Sarmatian limestones from the Şimleu Basin under shallow, normal littoral conditions in the shallow subtidal, intertidal and supratidal zones.

Acknowledgements. The paper is a contribution to the CNCSIS project granted to I. Bucur (8/1690/2005). We are thankful to the two reviewers, Sorin Filipescu and Robert Riding for their remarks and English improvements.

\section{R E F E R E N C E S}

Berekméri, L. 1980-1981, Biostratigrafia sectorului Ip-Sălaj. Nymphaea, Muzeul Tării Crişurilor, VIII-IX: 149-156.

Bucur, I. I., Nicorici, E. 1992, Calcareous algae from the Samarian deposits in the Şimleu Basin (Romania). Studia Universitatis Babes-Bolyai, Geologia, 37 (2): 3-7.

Bucur, I. I., Nicorici, E., Huică,. I. \& Ionesi, B., 1992, Calcareous microfacies in the Sarmatian deposits from Romania. Studia Universitatis Babes-Bolyai, Geologia, 37 (2): 9-16.

Burne, V.R., Moore, L.S. 1987, Microbialites: Organosedimentary deposits of benthic microbial communities. Palaios, 2: 241-254.

Chivu, M., Dragu, V., Enache, G., Isac, D. \& Mărgărit, E. 1966, Contribuții la stratigrafia Neogenului din bazinul Silvaniei. Dări de Seamă, Comitetul Geologic, LII (1): 239-248.

Clichici, O. 1971, Macrofauna depozitelor Sarmațiene din estul Bazinului Şimleu. Studia Universitatis BabesBolyai. Geologia-Mineralogia, XVI (2): 43-53.

Clichici, O. 1973, Stratigrafia Neogenului din estul Bazinului Şimleu. Ed. Acad. R.S.R., Bucureşti, 178 pp.

Flügel, E. 2004, Microfacies of carbonate rocks, analysis, interpretation and application, Springer, $976 \mathrm{pp}$.

Garcia-Pichel, F., Al-Horani, F.A., Farmer, J.D., Ludwig, R. \& Wade, B.D. 2004, Balance between microbial calcification and metazoan bioserosion in modern stromatolitic oncolites. Geobiology, 2: 49-57.

Givulescu, R. 1957, Contribuții la cunoaşterea faunei tortoniene şi sarmațiene din nord-estul munților Rezului. Buletinul Ştiințific al U.B.B, 1-2: 273-278.

Jones, B., Hunter, G.I. 1991, Coral to rhodolites to microbialites - a community replacement sequence indicative of regressive conditions. Palaios, 6: 54-66.

Kennard, M.J., James, P.N. 1986, Thrombolites and stromatolites: Two distinct types of microbial structures. Palaios, 1: 492-503.

Kershaw, S., Guo, L. 2002, Ecology and growth of giant calcified cyanobacterial mounds in the Pleistocene of central Greece. In Research advances in calcareous algae and microbial carbonates (Bucur, I., Filipescu, S., Eds.), Cluj University Press, Cluj Napoca, 145-156.

Kräutner, T. 1938, Recherches geologiques et petrographiques dans les massifs cristallins du NW de la Transylvanie (Țicău, Meseş, Rez, Măgura de Şimleul Silvaniei). Comptes Rendus Institut Geologique de Roumanie, XXII (1933-1934): 93-106.

Lucas, G., Montenat, C. 1967, Observations sur les structures internes et le développement des Microcodium. Bulletin de la Societé Géeologique de France, 7 (IX): 909-918.

Matyasovszky, I. 1881, Bericht ueber die geologische Aufnahmearbeiten im Komitat Szilagz (Zalău). Foldtany Közlöny, XII: 294-296.

Moissette, P., Saint-Martin, J.-P., Andrée, J.-P. \& Pestrea, S. 2002, L'association microbialite-bryozoaires dans le Messinien de Sicile et de Sardaigne. In L'Evénement messinien: approches paléobiologiques et paléoécologiques (Néraudeau, D., Goubert, E., Eds.), Geodiversitas, 24 (3): 611-623. 
Montaggioni, L.F., Camoin, G.F. 1993, Stromatolites associates with coralgal communities in Holocene highenergy reefs. Geology, 21: 149-152.

Nicorici, E. 1958, Noi forme de lamellibranchiate şi gastropode din tortonianul de la Tusa (reg.Crişana). Studia Universitatis Babes-Bolyai. Geologia, 1: 233-237.

Nicorici, E. 1962, Stratigrafia şi fauna depozitelor sarmațiene de pe bordura nord-estică a Munților Rez. Studia Universitatis Babes-Bolyai, Geologia, 2: 51-69.

Nicorici, E. 1963, Tortonianul de pe bordura nord-estică a Munțiilor Rezului. Comunicările Societății de Ştiințe Naturale şi Geografie, Comunicări de Geologie, II: 182192.

Nicorici, E. 1972, Stratigrafia neogenului din sudul Bazinului Şimleu. Editura Academiei R.S.R., Bucureşti, $159 \mathrm{pp}$.

Nicorici, E., Neagă, E. 1976, Prezența Sarmațianului inferior calcaros la Suplacul de Barcău. Dări de Seamă Institutul de Geologie şi Geofizică, LXII/4 (1974-1975): 225-228.

Oliver, N., Hantzpergne, P., Gaillard, Ch., Pittet, B., Leinfelder, R.R., Schmid, D.U. \& Werner, W. 2003, Microbialite morphology, structure and growth: a model of the Upper Jurassic reefs of the Chay Peninsula (Western France). Palaeogeography, Palaeoclimatology, Palaeoecology, 193: 383-404.

Paucă, M. 1954, Neogenul din bazinele externe ale Munţiilor Apuseni. Anuarul Comitetului Geologic, 27: 259-336.

Paucă, M. 1964, Bazinul neogen al Silvaniei. Anuarul Comitetului Geologic, XXXIV (I): 39-101.
Riding, R. 1991, Calcified cyanobacteria. In Calcareous algae and stromatolites (Riding, R., Ed.), Berlin: Springer Verlag, 55-87.

Riding, R. 2000, Microbial carbonates, the geological record of calcified bacterial-algal mats and biofilm. Sedimentology, 47 (Suppl.1): 179-214.

Saint Martin, J.-P. 2001, Implications de la présence de mud-mounds microbiens au Messinien (Sicile, Italie). Earth and Planetary Sciences 332: 527-534.

Saint Martin, J.-P., Conesa, G. \& Cornée, J.J. 1996, A new type of Messinian composite microbialite build-up (Salemi, Sicily, Italy). Sedimentary Geology 106: 51-63.

Saint-Martin, J.-P., Cornée, J.J., Muller, P., Conesa, G. \& Andreé, J.-P. 1997, Les constructions microbiennes du Messinien de meditérranée. Géobios, 20: 463-470.

Saint-Martin, J.-P., Müller, P., Moissette, P. \& Dulai, A. 2000, Coral microbialite environment in a Middle Miocene reef of Hungary. Palaeogeography, Palaeoclimatology, Palaeoecology, 160: 179-191.

Schmid, D.U., Leinfelder, R.R. \& Nose, M. 2001, Growth dynamics and ecology of Upper Jurassic mounds, with comparisons to Mid-Palaeozoic mounds. Sedimentary Geology, 145: 343-376.

Shapiro, R.S. 2000, A comment on the systematic confusion of thrombolites. Palaios, 15: 166-169.

Webb, G.E. 1987, Late Mississippian thrombolite bioherms from Pitkin Formation of northern Arkansas. Geological Society of America Bulletin, 99: 686-698. 

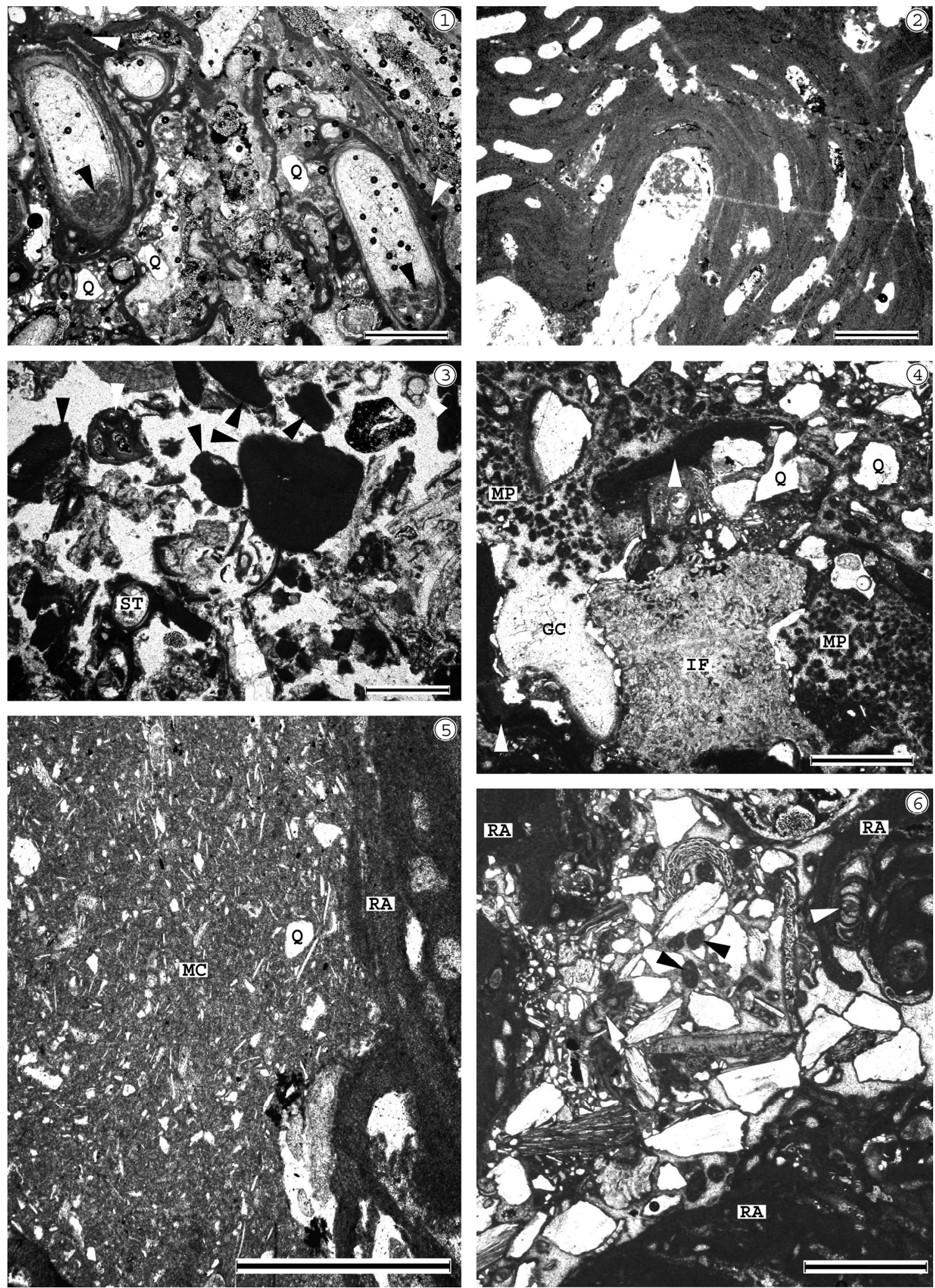

Plate I

Fig. 1. Worm tubes with geopetal sediment (black arrow) represented by calcitic peloids and "dog tooth"-type cement surrounded by nodules of red algae (white arrow). The terrigenous material is represented by quartz (Q). The matrix consists of micrite, probably of a microbial origin. Sample 285 (Tusa).

Fig. 2. Red algae (Mesophyllum sp.) encrusted on a dissolved bioclast subsequently replaced by granular cement. Sample 7930 (Tusa).

Fig. 3. Grainstone with fragments of red algae (black arrow), worm tubes (ST), and foraminifers (white arrow). The cement is represented by granular calcite. Sample 7930 (Tusa).

Fig. 4. Microbial peloids $(M P)$, terrigenous material $(Q)$, and nodules of red algae (white arrow). In the lower left corner, granular cement (GC) and encrusting foraminifers (IF) are noticeable. Sample 7934 (Tusa)

Fig. 5. Microbial crusts (MC) with bioclasts and terrigenous material (Q) encrusted by nodules of red algae (RA). Sample 7934 (Tusa).

Fig. 6. Boundstone with micritized red algae (RA), foraminifers (white arrow), and microbial peloids (black arrow). Terrigenous material represented by lighter grains. Sample 7935 (Tusa).

Scale bar is $1 \mathrm{~mm}$. 

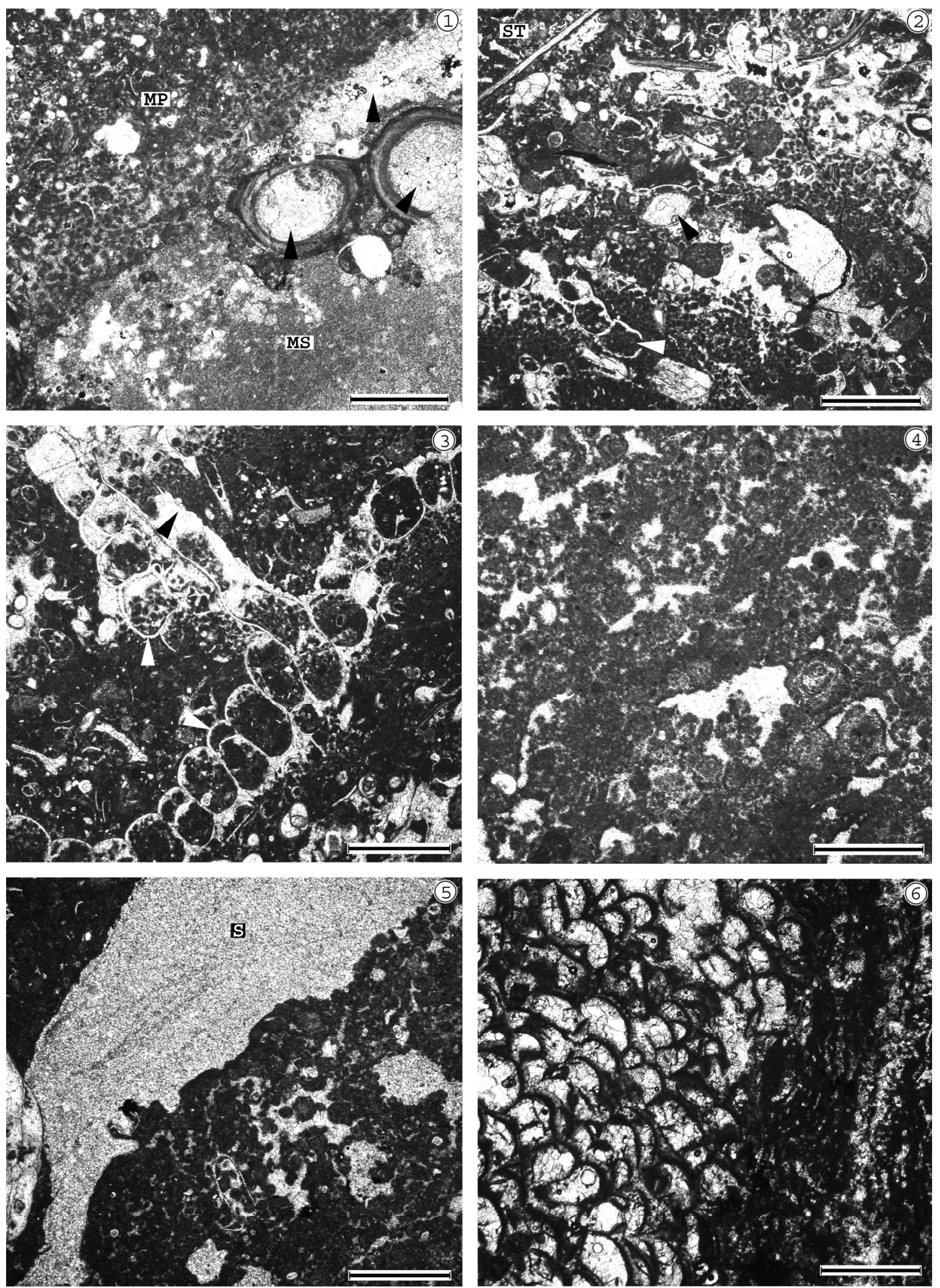

Plate II.

Fig. 1. Boundstone with microbial peloids (MP), and microsparite (MS). The worm tubes contain granular cement (black arrow). Sample 286 (Fizes).

Fig. 2. Laminated boundstone with frequent microbial peloids within the internal parts of the bryozoan zooecia (white arrow) and of the worm tubes (ST). Some foraminifers are completely recrystallized (black arrow). Sample 7948 (Fizes).

Fig. 3. Boundstone with microbial peloids within the bryozoan zooecia (white arrow). The granular cement postdates the fibrous cement (black arrow). Sample 7948 (Fizeș).

Fig. 4. Laminitic fenestral packstone consisting of agglutinated microbialites. The "stromatactis"-type fenestrae are filled with granular cement. Sample 7949 (Fizeş).

Fig. 5. Vadose silt (S) in-between microbial peloids Sample 7949 (Fizeş).

Fig. 6. Boundstone with bryozoans surrounded by microbialitic crusts. Sample 7950 (Fizeş). Scale bar is $1 \mathrm{~mm}$. 

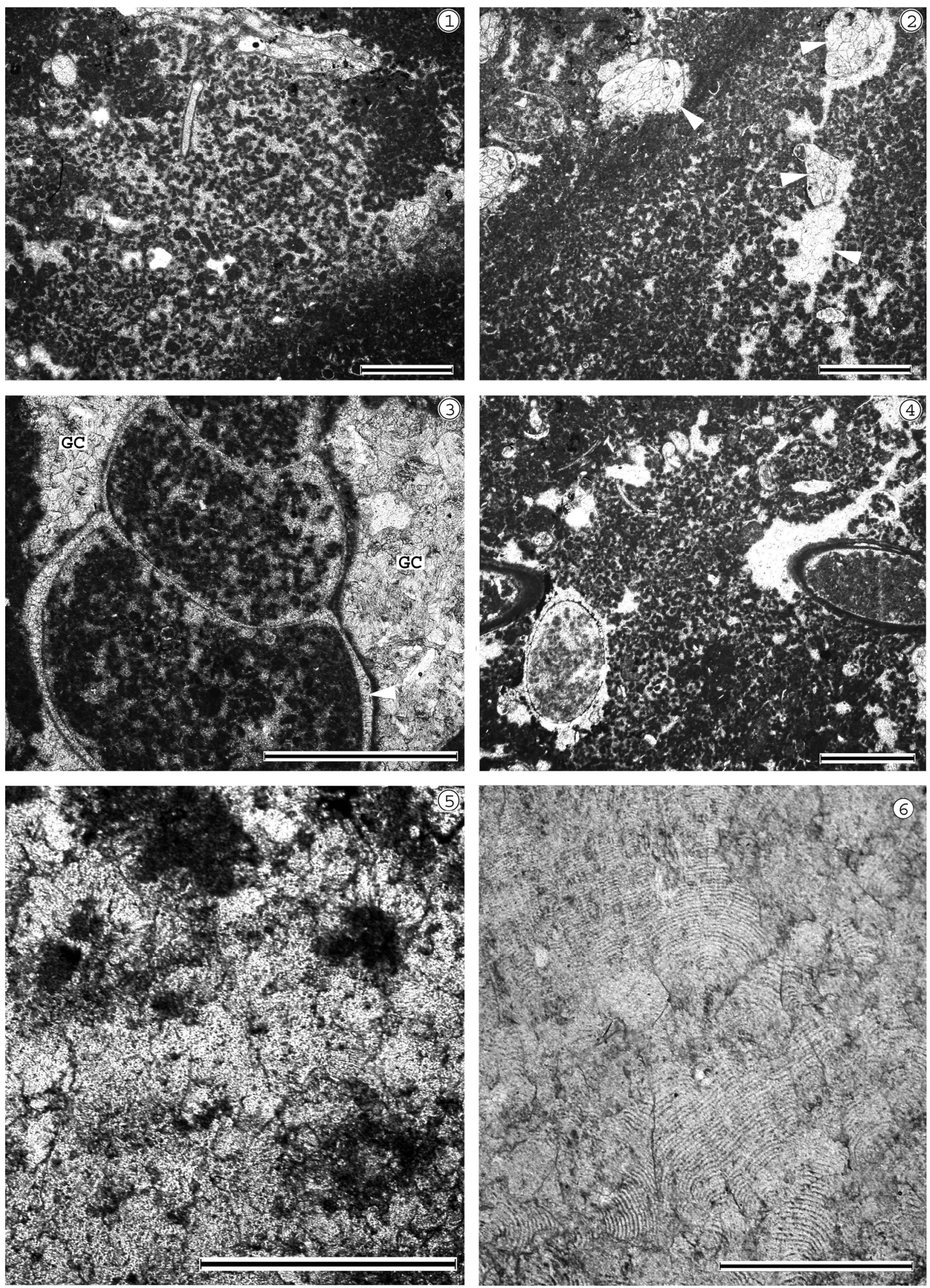

Plate III

Fig. 1. Thrombolites with granular cement. Sample 7960 (Fizeş).

Fig. 2. Laminated peloidal packstone-grainstone. Some bioclasts (arrow) are completely recrystallized. Sample 7968 (Fizes).

Fig. 3. Gastropod filled with microbial peloids and lined by isopachous cement along the shell margin (arrow). The remainder is granular cement (GC). Sample 7970 (Fizes).

Fig. 4. Thrombolitic peloidal grainstone-packstone. The worm tubes are filled with microbial peloids Sample 7977 (Preuteasa).

Fig. 5. Microcodium sp. Sample 7979 (Preuteasa).

Fig. 6. Botryoidal cement with microstromatolitic aspect within a bryozoan-annelid boundstone. Sample 7979 (Preuteasa).

Scale bar is $1 \mathrm{~mm}$. 

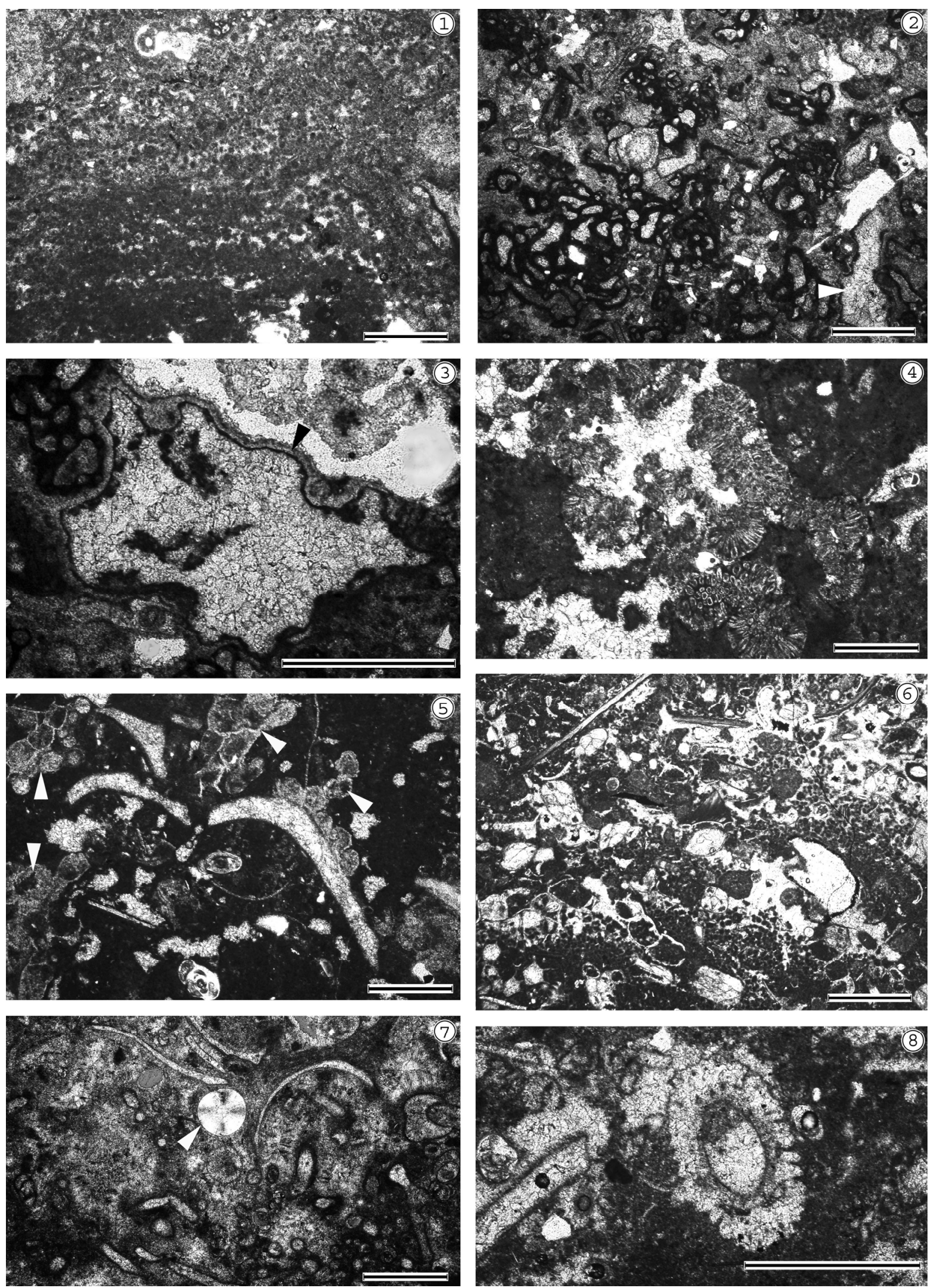

Plate IV

Fig. 1. Fenestral laminitated bindstone with stratiform stromatolitic structures. Sample 8007 (Plopiş, Varului Hill).

Fig. 2. Boundstone consisting of intensely micritized red algae and microbial crusts. Grain dissolution and "dog tooth"-type cement (arrow) are noticeable. Sample 8008 (Plopiş, Varului Hill).

Fig. 3. Crusts of isopachous cement (arrow) preceding granular cement. Sample 8008 (Plopiş, Varului Hill).

Fig. 4. Fenestral bindstone with bryozoans and Microcodium. Sample 8009 (Plopiş, Varului Hill).

Fig. 5. Boundstone with bryozoans (arrow) and other bioclasts embedded in microbial micrite. Sample 8011 (Plopiş, Varului Hill).

Fig. 6. Stromatolitic structures within boundstone with bryozoans. Sample 7948 (Fizes, Dumbrava Hill).

Fig. 7. Bioclastic packstone with numerous miliolids, sometimes silicified (arrow). Sample 8013 (Plopiş, Varului Hill).

Fig. 8. Bioclastic packstone with dasyclads (Cymopolia sp.). Sample 8012 (Plopiş, Varului Hill).

Scale bar is $1 \mathrm{~mm}$. 

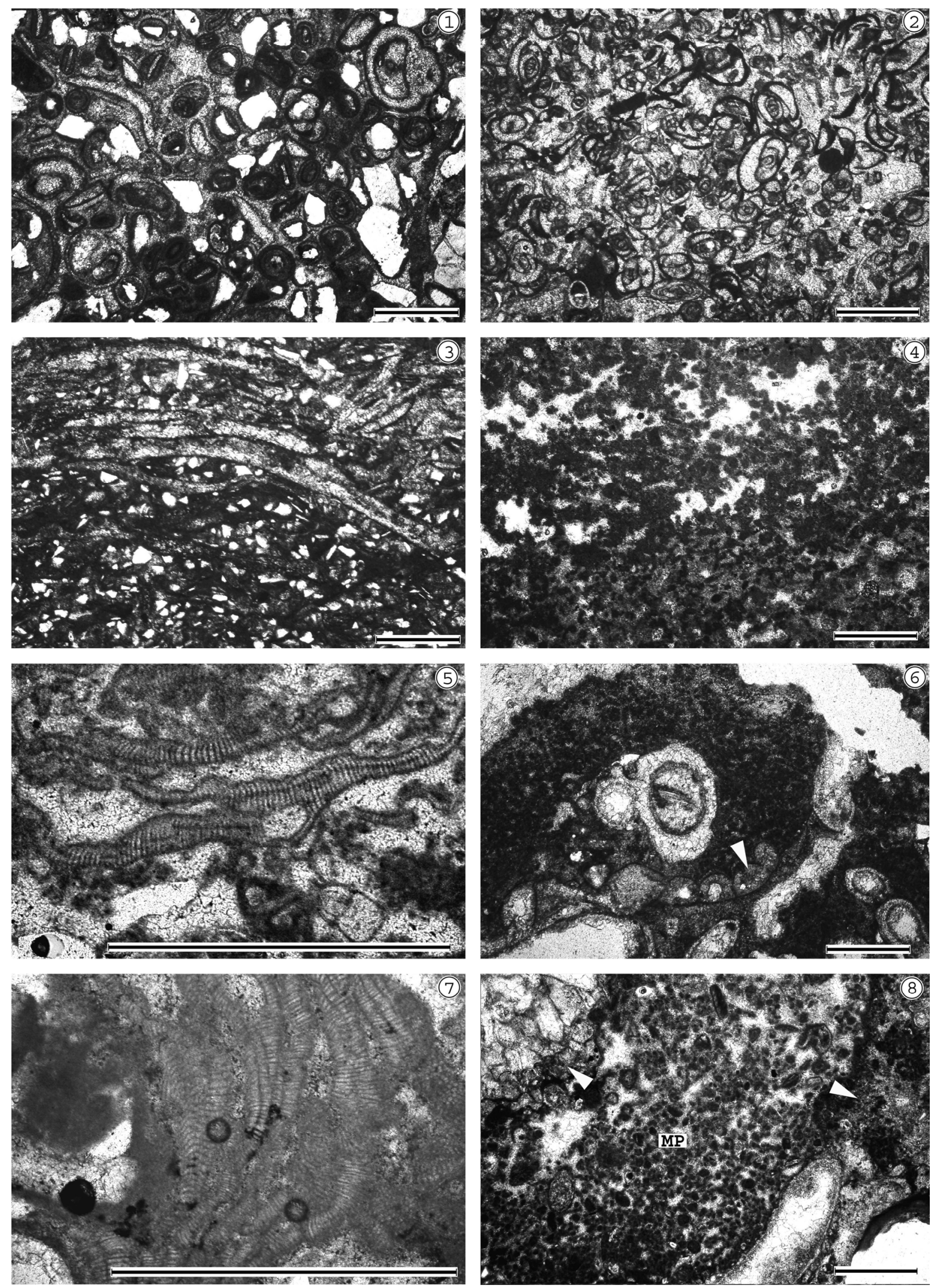

Plate V

Fig. 1. Bioclastic grainstone with terrigenous material. Sample 8018 (Plopis, Ghiurchii Valley).

Fig. 2. Grainstone with miliolids. A second generation granular cement fills the bioclasts. Sample 7990 (Plopiş, Luşoru).

Fig. 3. Bioclastic packstone. The bioclasts are surrounded by microbial crusts. Compaction features are noticeable. Sample 7994 (Plopis,

Luşoru).

Fig. 4. Peloidal structures within laminated stromatolites. Sample 8025 (Halmăşd).

Fig. 5. Nodules of red algae (Titanoderma ucrainica). Sample 8028 (Halmăşd).

Fig. 6. Worm tubes surrounded by microbial peloids within thrombolitic structures. The bryozoans (arrow) show a fibrous structure. Sample 8034 (Halmăşd).

Fig. 7. Nodules of red algae (Titanoderma ucrainica). Sample 8050 (Halmăşd).

Fig. 8. Microbial peloids (MP) and bryozoans (arrow) within thrombolitic structures. Sample 7963 (Fizeş).

Scale bar is $1 \mathrm{~mm}$ 